\title{
Concentration-dependent radiosensitizing effect of docetaxel in esophageal squamous cell carcinoma cells
}

\author{
SHOHEI MIYANAGA ${ }^{1}$, ITASU NINOMIYA ${ }^{1}$, TOMOYA TSUKADA ${ }^{1}$, KOICHI OKAMOTO ${ }^{1}$, SHINICHI HARADA $^{2}$, \\ SHINICHI NAKANUMA ${ }^{1}$, SEISHO SAKAI ${ }^{1}$, ISAMU MAKINO ${ }^{1}$, JUN KINOSHITA ${ }^{1}$, HIRONORI HAYASHI ${ }^{1}$, \\ KEISHI NAKAMURA ${ }^{1}$, KATSUNOBU OYAMA ${ }^{1}$, HISATOSHI NAKAGAWARA ${ }^{1}$, TOMOHARU MIYASHITA ${ }^{1}$, \\ HIDEHIRO TAJIMA $^{1}$, HIROYUKI TAKAMURA ${ }^{1}$, SACHIO FUSHIDA ${ }^{1}$ and TETSUO OHTA ${ }^{1}$ \\ ${ }^{1}$ Department of Gastroenterological Surgery, Division of Cancer Medicine, Graduate School of Medical Science, \\ ${ }^{2}$ Center for Biomedical Research and Education, School of Medical Science, Kanazawa University, Kanazawa 920-8641, Japan
}

Received October 12, 2015; Accepted November 13, 2015

DOI: 10.3892/ijo.2015.3291

\begin{abstract}
Taxanes, paclitaxel and docetaxel (DTX) are anticancer agents that exhibit cytotoxicity by inhibiting microtubule polymerization. They enhance the radiosensitivity of various cancers by blocking the cell cycle in the most radiosensitive G2/M phase. Recently, taxanes have been reported to have different mechanisms of action depending on dose intensity. However, the mechanism of the radio-enhancing effect of DTX in relation to the drug dose intensity is not clearly understood. In the present study, we experimentally investigated the radio-enhancing effects of various concentrations of DTX against esophageal squamous cell cancer (ESCC); KES cells were used for in vitro confirmation of the effective administration schedule for DTX in chemoradiotherapy involving ESCC. DTX enhanced radiation cell killing in a concentration-dependent manner in KES cells. High cytotoxic concentrations ( $>10 \mathrm{nM})$ of DTX strongly enhanced radiosensitivity. Low concentrations $(<1 \mathrm{nM})$ of DTX that did not have a cytotoxic effect showed a radio-enhancing effect by inducing DNA double strand breaks and apoptosis after irradiation. Low and high concentrations of DTX induced radiosensitive G0/G1 and G2/M phase arrest, respectively in KES cells. Cells treated with high concentrations of DTX exhibited nuclear aggregation associated with apoptotic change. In contrast,
\end{abstract}

Correspondence to: Dr Itasu Ninomiya, Department of Gastroenterological Surgery, Division of Cancer Medicine, Graduate School of Medical Science, Kanazawa University, 13-1 Takara-machi, Kanazawa 920-8641, Japan

E-mail: nino@staff.kanazawa-u.ac.jp

Abbreviations: CRT, chemoradiotherapy; DTX, docetaxel; ESCC, esophageal squamous cell carcinoma; MTT, 3-(4,5-dimethylthiazol2-yl)-2,5-diphenyltetrazolium bromide; PBS, phosphate-buffered saline; PTX, paclitaxel; $\gamma \mathrm{H} 2 \mathrm{AX}, \mathrm{H} 2 \mathrm{AX}$ phosphorylation

Key words: esophageal cancer, docetaxel, radiation, radiosensitizing effect, cell cycle, double-strand DNA breaks cells treated with low concentrations of DTX displayed multinucleation or unequal division. In conclusion, enhancement of the radiosensitivity of ESCC cells by DTX was demonstrated, even using nanomolar concentrations that did not have a cytotoxic effect. DTX has different radio-enhancing mechanisms depending on its concentration. Therefore, weekly administration of DTX might effectively enhance radiation cytotoxicity in the treatment of ESCC.

\section{Introduction}

The treatment outcome for patients with esophageal squamous cell carcinoma (ESCC) is poor, despite improvements in care (1). There have been several treatment strategies for ESCC; among them, surgery is considered as the most effective. However, patients with unresectable or inoperable disease are usually treated with chemoradiotherapy (CRT) in the clinic; this is considered to be an effective therapeutic strategy (2-4). At present, the standard regimen for CRT regarding ESCC is the combined use of cisplatin and 5-fluorouracil with radiotherapy. CRT sometimes induces severe adverse events, together with a favorable therapeutic effect $(5,6)$. Therefore, a CRT regimen involving reduced side effects is desirable. Taxanes including docetaxel (DTX) and paclitaxel (PTX) are anticancer agents that exhibit cytotoxicity by inhibiting microtubule polymerization; they are attracting attention as one of the key drugs in the treatment of a variety of carcinomas (7). Among them, DTX is useful for many types of cancer including nasopharyngeal (8), gastric $(9,10)$, breast (11), prostate (12), lung (13), thyroid (14) and esophageal cancer (15). It has been widely recognized that DTX enhances radiosensitivity in various cancers in vitro and in vivo (16-18). To date, DTX has been shown to be clinically useful as an active agent in CRT treatment regimens involving laryngeal/hypopharyngeal cancers (19). DTX has been used in combination with cisplatin as an agent for CRT in non-small cell lung cancer (20). A phase I/II study involving DTX and cisplatin with concurrent thoracic radiotherapy for locally advanced non-small cell lung cancer has shown that the dose limiting toxicity is radiation esophagitis (21). One of the approaches regarding the reduction of adverse events in CRT is the administration of low dose DTX. 
Recently, there have been several reports concerning the favorable effects of weekly administration of low dose DTX as a radiosensitizer in head and neck cancer (22-26), non-small cell lung cancer $(27,28)$ and ovarian cancer $(29)$. These studies have shown that CRT with low dose DTX has an antitumor effect comparable to high dose DTX, and induce less adverse events. In recent years, CRT in combination with weekly DTX has been performed safely in patients with advanced inoperable ESCC (30,31). Preoperative CRT for locally advanced ESCC using DTX results in similar or better long-term outcomes as compared with cisplatin and 5-fluorouracil based CRT, despite the patients demonstrating a better pathological response to cisplatin and 5-fluorouracil based CRT when compared with DTX based CRT (32).

DTX induces microtubule modification and causes cells to accumulate in the radiosensitive $\mathrm{G} 2 / \mathrm{M}$ phase of the cell cycle (33). Recently, taxanes have been reported to have a different mechanism of action depending on dose intensity (34-36). Most studies that have indicated a dual mechanism of action for taxanes have been reported using PTX $(34,36)$. The mechanism of the radio-enhancing effect of DTX in relation to the dose intensity is not clearly understood.

In the present study, we experimentally investigated the radio-enhancing effects of various concentrations of DTX against ESCC cells to elucidate an effective administration schedule for DTX regarding CRT for ESCC. We also examined the concentration-dependent radio-enhancing mechanism in respect to cell cycle arrest in ESCC cells.

\section{Materials and methods}

Cell line and treatment. The esophageal squamous cell carcinoma cell line KES has been established in our laboratory from endoscopic biopsy specimens obtained from a patient carrying well differentiated esophageal squamous cell carcinoma. KES was cultured in RPMI-1640 (Invitrogen, Osaka, Japan) supplemented with $10 \%$ heat-inactivated fetal bovine serum (Nissui Pharmaceutical Co. Ltd., Tokyo, Japan), 100 IU/ml penicillin, $100 \mu \mathrm{g} / \mathrm{ml}$ streptomycin (Invitrogen), $2 \mathrm{mM}$ glutamine (Nissui Pharmaceutical Co. Ltd.) and $0.5 \mathrm{mM}$ sodium pyruvate at $37^{\circ} \mathrm{C}$ in a humidified atmosphere of $\mathrm{CO}_{2}$ in air. DTX was dissolved in phosphate-buffered saline (PBS) to a stock concentration of $200 \mathrm{nM}$ and stored at $-20^{\circ} \mathrm{C}$. Cultures were irradiated using MBR-1520R-3 X-ray radiation apparatus (Hitachi Medicotechnology, Hitachi, Japan) at a dose rate of $1 \mathrm{~Gy} / \mathrm{min}$. Power output of the X-rays used for irradiation was $125 \mathrm{kV}$ and the beam current was $20 \mathrm{~mA}$. Forward-scattered radiation, and $0.5 \mathrm{~mm} \mathrm{Al}$ and $0.2 \mathrm{~mm} \mathrm{Cu}$ filters were used.

Cell growth assay. The viability of cells treated with DTX was determined using a standard 3-(4,5-dimethylthiazol-2-yl)2,5-diphenyltetrazolium bromide (MTT) assay. KES cells were treated with DTX at various concentrations $(0.1-50 \mathrm{nM})$ for $48 \mathrm{~h}$. The percentage inhibition was determined by comparing the cell density of the drug-treated cells with that of untreated controls. All experiments were repeated at least three times.

Cell cycle analysis. KES cells were treated with DTX at various concentrations $(0.1-50 \mathrm{nM})$, following treatment periods of $0,3,6,12,24$ and $48 \mathrm{~h}$. Cells were stained with propidium iodide and analyzed using flow cytometry. The percentages of the cells in the sub-G0, G0/G1, S and G2/M phases were calculated.

Nuclear form. Alteration of the nuclear form of the KES cells treated with DTX was analyzed. KES cells were treated with DTX at various concentrations $(0,1$ and $10 \mathrm{nM})$, and were fixed with $4 \%$ formaldehyde and stained with Hoechst 33342 (Thermo Fisher Scientific K.K, Yokohama, Japan). Nuclear form was examined using an Olympus immunofluorescence microscope (BX50/BX-FLA, Olympus, Tokyo, Japan).

Clonogenic assay. The cells were plated into dishes and allowed to attach for $4 \mathrm{~h}$. The medium was then replaced by a medium with or without DTX. Following incubation for $12 \mathrm{~h}$, the cells were irradiated at various doses (2-6 Gy). The cells were harvested using trypsinization, counted, and known concentrations of cells were re-plated into $100-\mathrm{mm}$ culture dishes and returned to the incubator. After incubation for 7-10 days, the cell colonies were fixed and stained with $0.1 \%$ crystal violet. Colonies of $>50$ cells were manually counted to determine survival.

Assessment of apoptosis. The Annexin V binding assay was used to assess phosphatidylserine externalization as a marker of apoptosis using the Pacific Blue ${ }^{\mathrm{TM}}$ Annexin V/SYTOX ${ }^{\circledR}$ AADvanced $^{\mathrm{TM}}$ Apoptosis kit (Invitrogen) according to the manufacturer's instructions. The extent of apoptosis was quantified using flow cytometry.

Immunofluorescent cytochemistry. Cells were cultured on Lab-Tec chamber slides (Nalge Nunc International, Rochester, NY, USA). The cells were then treated with various concentrations of DTX $(0,1$ and $10 \mathrm{nM})$ for $12 \mathrm{~h}$ and subsequently irradiated. They were fixed in a mixture of methanol and acetone (1:1) for $15 \mathrm{~min}$. The slides were immersed in methanol containing $0.3 \% \mathrm{H}_{2} \mathrm{O}_{2}$ for $30 \mathrm{~min}$, blocked with $3.3 \%$ normal goat serum in PBS and incubated with anti-phosphohistone H2AX (Ser 139) (Cell Signaling Technology, MA, USA) at $4^{\circ} \mathrm{C}$. After sections were washed in PBS, immunoreactivity was visualized by incubating them in anti-rabbit IgG antibody conjugated with Alexa Flour 488 (Molecular Probes, Eugene, OR, Danvers, MA, USA) for $1 \mathrm{~h}$ at room temperature. The nucleus was counterstained with Hoechst 33342 (Thermo Fisher Scientific K.K). The slides were examined with an Olympus immunofluorescence microscope (BX50/BX-FLA, Olympus).

\section{Results}

Antitumor efficacy of DTX. The inhibitory effect of DTX on KES cell growth was assessed using the MTT assay. Cells were treated with various concentrations of DTX for $48 \mathrm{~h}$. DTX inhibited KES cell growth in a dose-dependent manner (Fig. 1). The $50 \%$ inhibitory concentration $\left(\mathrm{IC}_{50}\right)$ value of DTX was $2.4 \mathrm{nM}$ and the $20 \%$ inhibitory concentration $\left(\mathrm{IC}_{20}\right)$ value was $1.1 \mathrm{nM}$.

Cell cycle. First, no obvious cell cycle change was observed below 6-h exposure to DTX at any concentration. After 12-h incubation of KES cells with the medium and high concentra- 


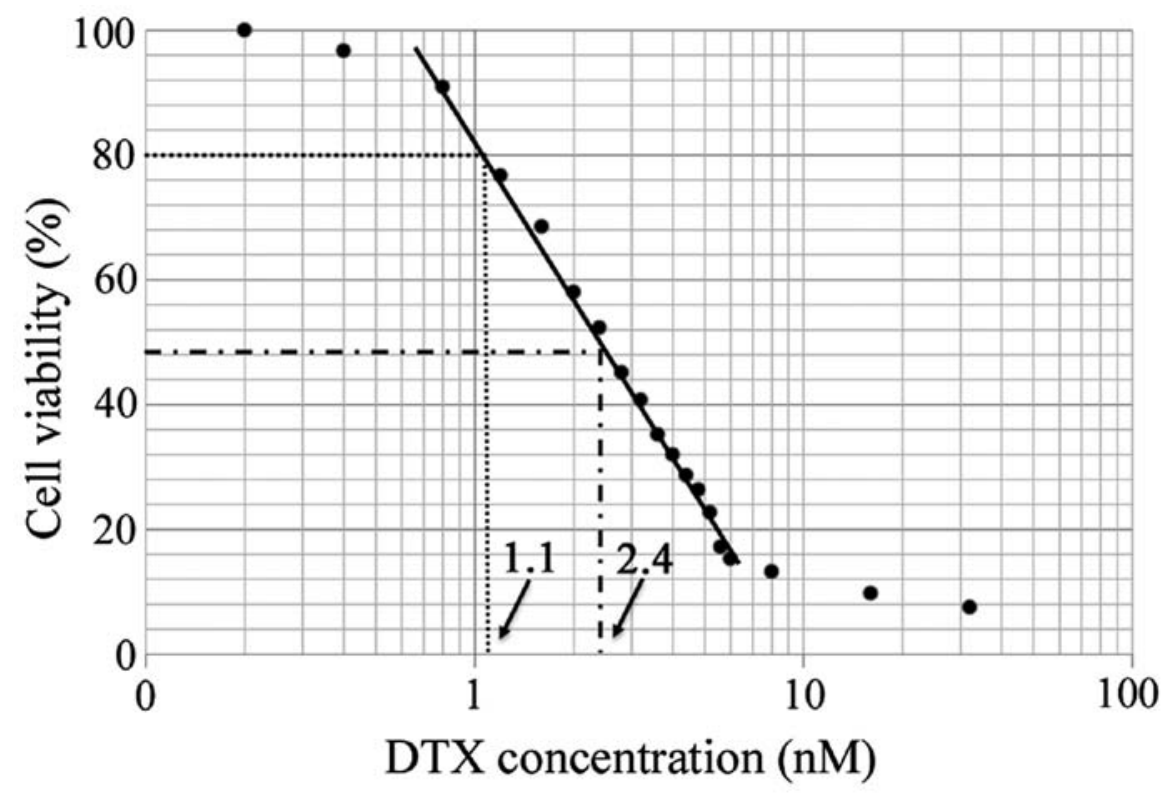

Figure 1. Antitumor efficacy of docetaxel (DTX). Antitumor efficacy of DTX was assessed using the MTT assay. KES cells were treated with DTX at various concentrations $(0.1-50 \mathrm{nM})$ for $48 \mathrm{~h}$.

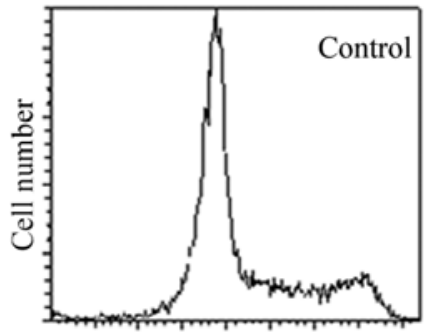

DNA content

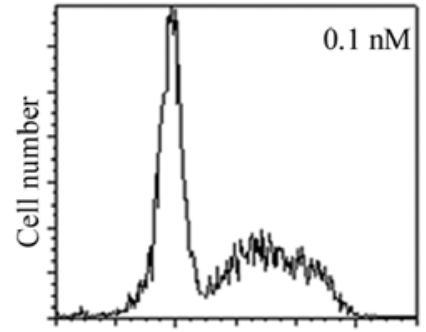

DNA content

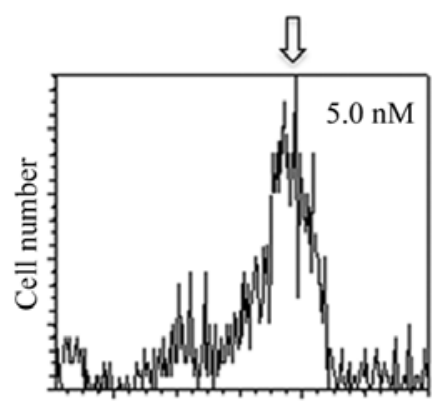

DNA content

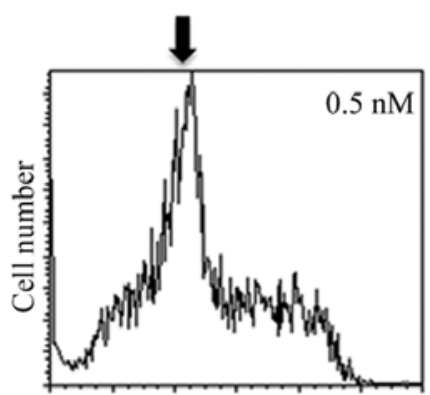

DNA content

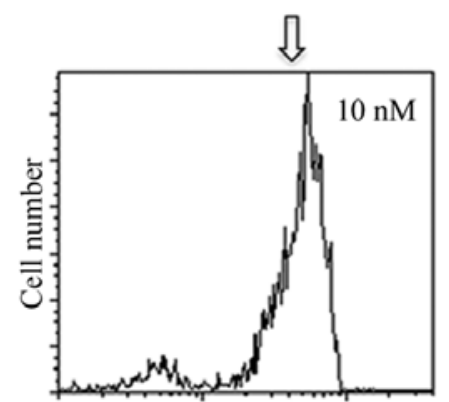

DNA content

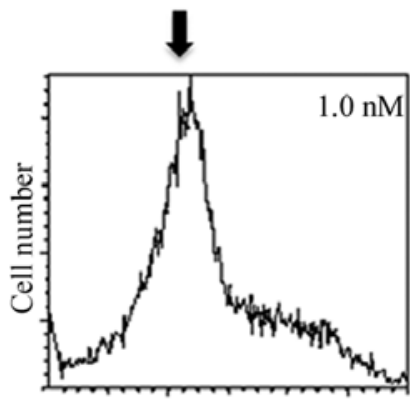

DNA content

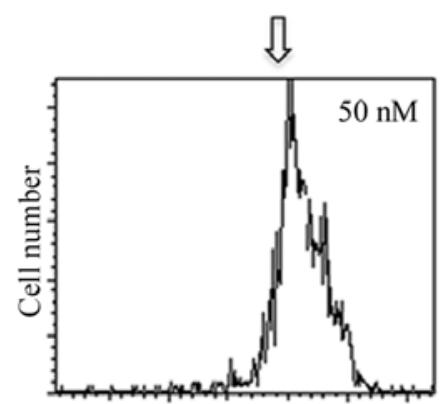

DNA content

Figure 2. Cell cycle alteration caused by docetaxel (DTX) in a concentration-dependent manner. KES cells were incubated for $12 \mathrm{~h}$ with various concentrations of DTX $(0,0.1,0.5,1.0,5,10$ and $50 \mathrm{nM})$. Cell cycle alteration after treatment was analyzed using flow cytometry. Relative to the control $(0 \mathrm{nM})$, cells treated with low concentrations of DTX $(0.5-1.0 \mathrm{nM})$ were arrested in the G1 phase (black arrow). Cells treated with high concentrations of DTX (5-50 nM) were arrested at G2-M phase (white arrow).

tions of DTX (5-50 $\mathrm{nM}$ and more), $265 \%$ of the cells were arrested in the G2-M phase with a 4-n content of DNA (Figs. 2 and 3 and Table I). The accumulation of cells in the sub-G0 and G0/G1 phases was observed after treatment using low concentrations of DTX $(0.5-1 \mathrm{nM})$. Low concentrations of DTX led to the development of hypodiploid cells.
Nuclear form. KES cells were stained with Hoechst 33342 after treatment with two concentrations of DTX $(0.1$ and $10 \mathrm{nM})$ for $12 \mathrm{~h}$. Nuclear form was investigated using an immunofluorescence microscope. Cells treated with a high concentration of DTX exhibited nuclear aggregation associated with apoptotic change in some nuclei. In contrast, cells treated with a low 


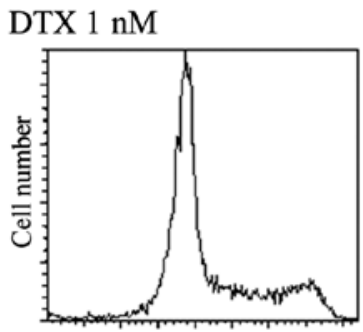

DNA content

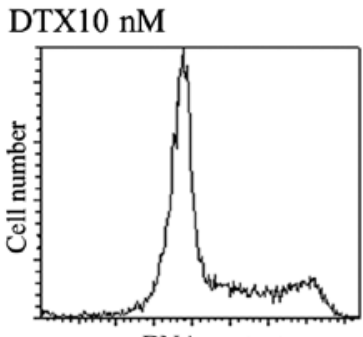

DNA content

$0 \mathrm{~h}$

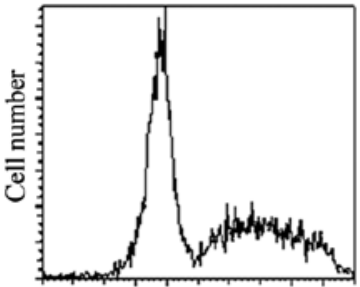

DNA content

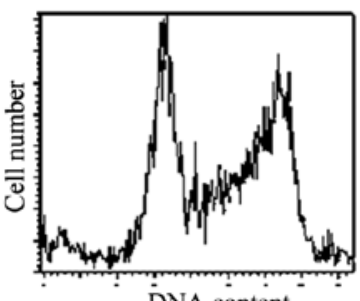

$6 \mathrm{~h}$

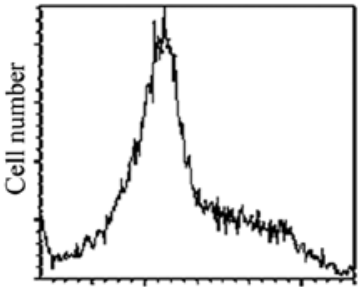

DNA content

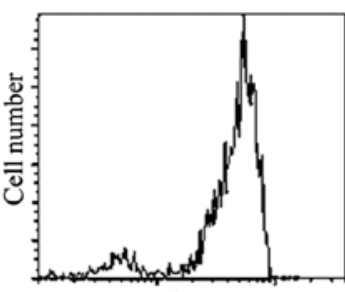

DNA content

$12 \mathrm{~h}$

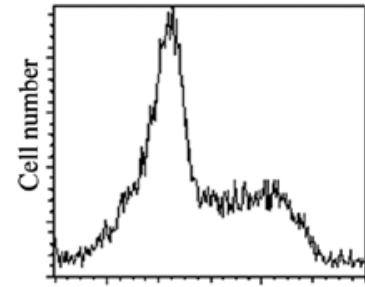

DNA content

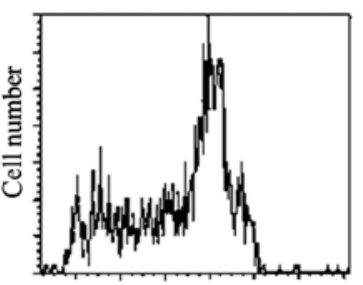

DNA content

$24 \mathrm{~h}$

\section{DTX exposure time}

Figure 3. Sequential cell cycle alteration caused by docetaxel (DTX). KES cells were incubated with low (1.0 nM) or high (10 nM) concentrations of DTX for $0-48$ h. Cell cycle alteration after treatment was analyzed by flow cytometry.

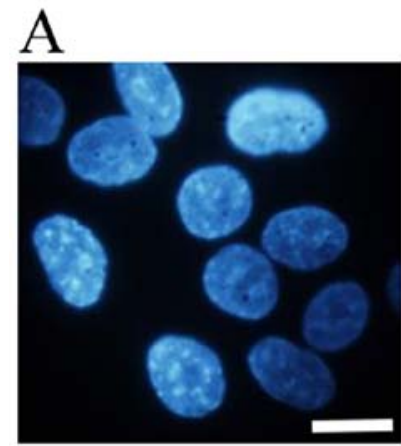

$0 \mathrm{nM}$ (control)
$\mathrm{B}$

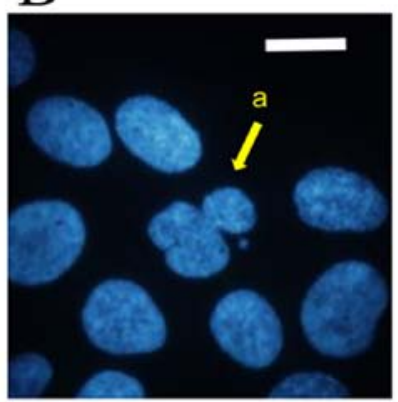

$1 \mathrm{nM}$

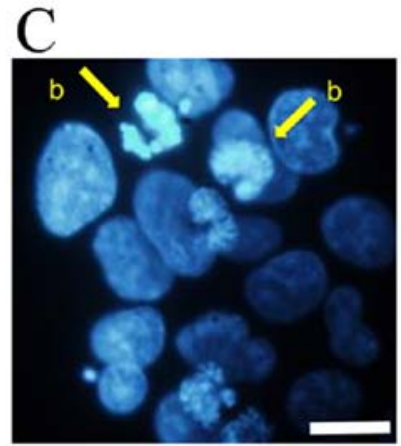

$10 \mathrm{nM}$

\section{DTX concentration}

Figure 4. Effects of docetaxel (DTX) on nuclear morphology. KES cells were treated with various concentrations of DTX (0 nM, $1 \mathrm{nM}$ and $10 \mathrm{nM}$ ) for $12 \mathrm{~h}$. Cells were fixed with $4 \%$ formaldehyde and stained with Hoechst 33342. Nuclear morphology was examined using an immunofluorescence microscope. (A) Control. (B) Cells treated with a low concentration DTX (1 nM). Some nuclei show multi-nucleation or unequal division (arrow a). (C) Cells treated with a high concentration of DTX $(10 \mathrm{nM})$. Some nuclei exhibit nuclear aggregation associated with apoptotic change (arrow b). Scale bar, $10 \mu \mathrm{m}$.

Table I. Cell cycle distribution of KES cells following docetaxel (DTX) treatment.

Proportion of cell cycle fraction $(\%)$

$\begin{array}{llll}\begin{array}{l}\text { DTX concentration } \\ (\mathrm{nM})\end{array} & \text { Sub-G0/G1+G0/G1 } & \text { S } & \text { G2/M }\end{array}$

\begin{tabular}{rrrr}
\hline 0 & 59.0 & 11.6 & 29.2 \\
1 & 71.9 & 9.6 & 18.3 \\
10 & 21.1 & 11.8 & 66.8 \\
\hline
\end{tabular}

concentration of DTX exhibited multi-nucleation or unequal division in some nuclei (Fig. 4).

Radiosensitizing effect of DTX. The radio-sensitizing effect of DTX was assessed using a clonogenic assay. As expected, cells treated with $10 \mathrm{nM}$ DTX (high concentration) had enhanced radio-sensitivity (Fig. 5). In addition, cells treated with $1 \mathrm{nM}$ DTX (low concentration) exhibited enhanced radio-sensitivity although it was slightly lower than after treatment with the high concentration of DTX.

Enhancement of radiation-induced apoptosis using DTX. The apoptotic response to irradiation alone or the combination of 


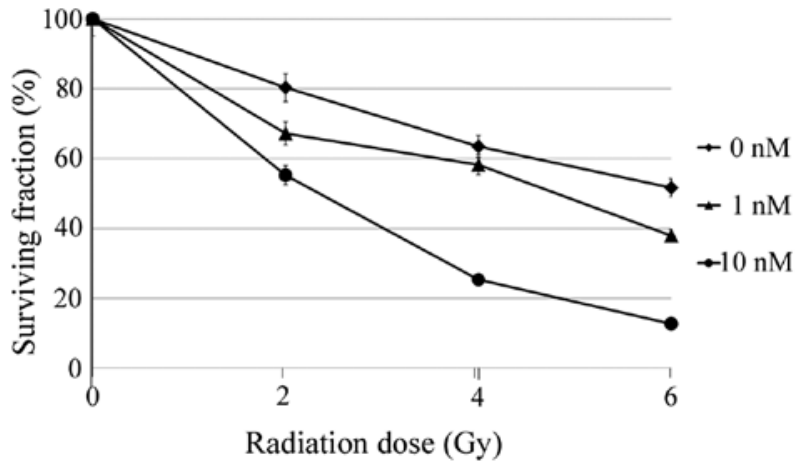

Figure 5. Radiosensitizing effect of docetaxel (DTX) on KES cells. The survival fraction of KES cells after radiation treatment in combination with DTX (low concentration, $1 \mathrm{nM}$; high concentration, $10 \mathrm{nM}$ ) for $12 \mathrm{~h}$, or after radiation treatment without DTX, was measured by clonogenic assay. Results represent the means of three independent experiments with standard errors. irradiation and DTX treatment was assessed. After treatment with various concentrations of DTX $(0,1$ and $10 \mathrm{nM})$ for $12 \mathrm{~h}$, KES cells were irradiated (4 Gy) and returned to culture for $6 \mathrm{~h}$. The cells were then examined for the detection of apoptosis. Even without DTX, apoptosis was induced in a few cells by irradiation. A high concentration of DTX (10 nM) remarkably enhanced radiation-induced apoptosis. In addition, a low concentration of DTX $(1 \mathrm{nM})$ also enhanced radiation and induced a certain degree of apoptosis in KES cells (Fig. 6).

Enhancement of radiation induced DNA double strand breaks (DSBs) using DTX. After irradiation, H2AX phosphorylation $(\gamma \mathrm{H} 2 \mathrm{AX})$ was measured as an indicator of DNA DSBs using immunofluorescent cytochemistry. In the absence of DTX, few cells showed $\gamma \mathrm{H} 2 \mathrm{AX}$ foci after irradiation. A high concentration of DTX $(10 \mathrm{nM})$ induced multiple $\gamma \mathrm{H} 2 \mathrm{AX}$ foci after
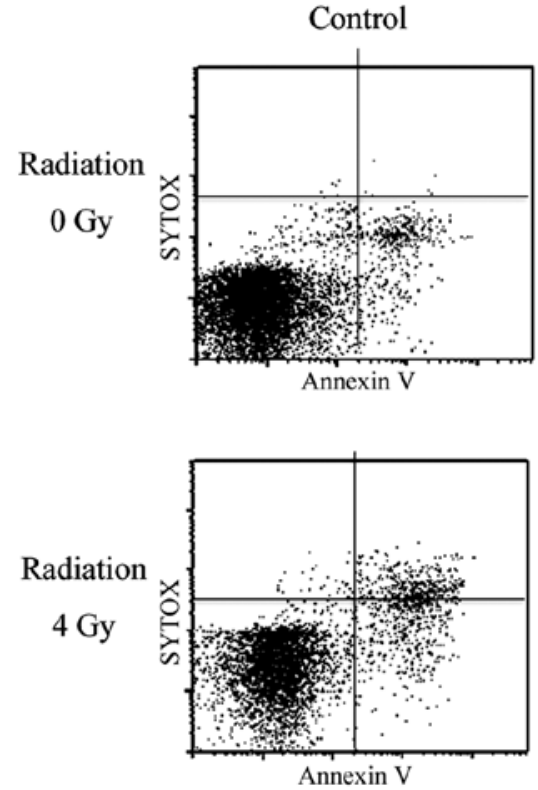

DTX $1 \mathrm{nM}$
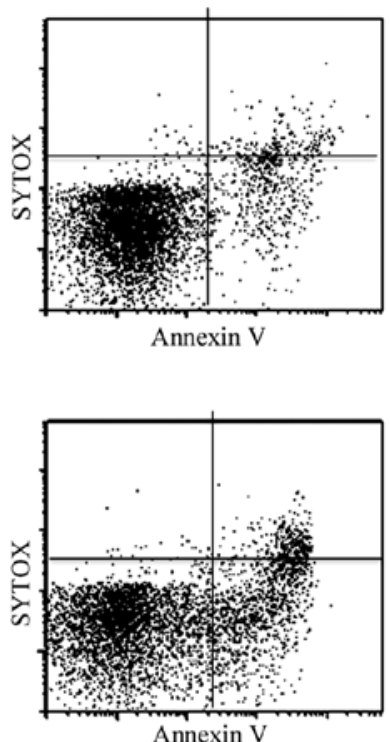

DTX $10 \mathrm{nM}$

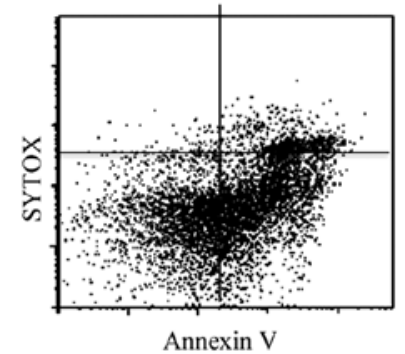

Annexin V

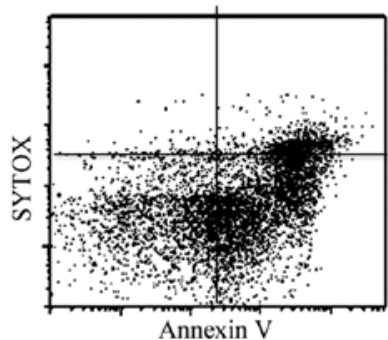

Figure 6. The effect of docetaxel (DTX) on apoptosis after irradiation. KES cells were treated with DTX (low concentration, $1 \mathrm{nM}$; high concentration, $10 \mathrm{nM}$ ) for $12 \mathrm{~h}$ and irradiated (dose, $4 \mathrm{~Gy}$ ). Phosphatidylserine externalization as a marker of apoptosis was assessed by means of the Annexin $\mathrm{V}$ binding assay using the Pacific Blue Annexin V/SYTOX AADvanced Apoptosis kit. The extent of apoptosis was quantified using flow cytometry. Early apoptotic populations were localized in the lower right quadrants.

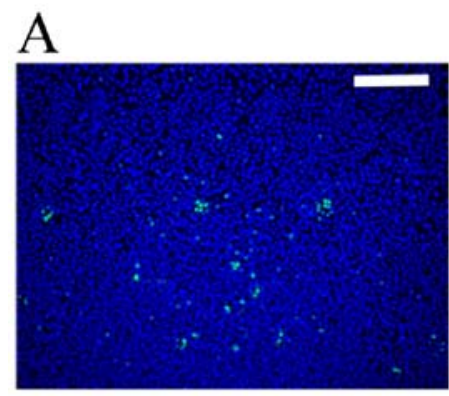

$0 \mathrm{nM}$ (control)

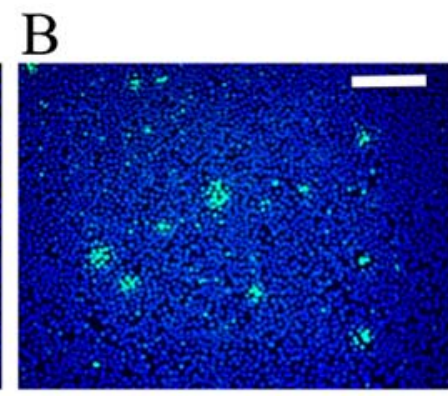

$1 \mathrm{nM}$

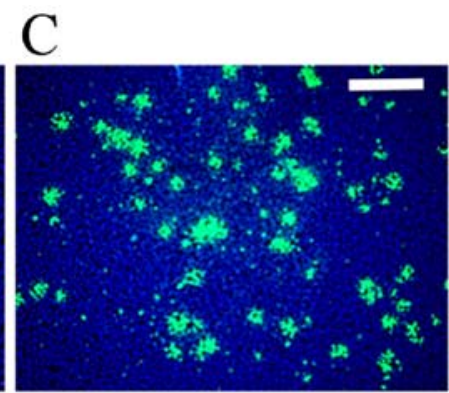

$10 \mathrm{nM}$

\section{DTX concentration}

Figure 7. The effect of docetaxel (DTX) on radiation-induced DNA double strand breaks (DSBs). KES cells were treated with DTX for $12 \mathrm{~h}$ and irradiated (dose, 4 Gy). DNA DSBs were assessed by observation of phosphorylated histone H2AX ( $\gamma$-H2AX) foci stained with Alexa Flour 488 ( $\gamma$ H2AX) (green) using an immunofluorescence microscope. The cell nucleus was stained with Hoechst 33342 (blue). (A) Control (0 nM). (B) Cells treated with a low concentration of DTX $(1 \mathrm{nM})$. (C) Cells treated with a high concentrationof DTX $(10 \mathrm{nM})$. Scale bar, $1 \mu \mathrm{m}$. 
irradiation in many cells. A low concentration of DTX $(1 \mathrm{nM})$ induced a certain degree of $\gamma \mathrm{H} 2 \mathrm{AX}$ foci after irradiation in several KES cells (Fig. 7).

\section{Discussion}

In the present study, we found that DTX had a concentrationdependent radio-enhancing effect in ESCC cells. A high cytotoxic concentration ( $>10 \mathrm{nM}$ ) of DTX strongly enhanced radiosensitivity. A low concentration $(<1 \mathrm{nM})$ of DTX, that did not elicit a cytotoxic effect, also achieved a radio-enhancing effect by inducing DNA DSBs and apoptosis after irradiation. Low and high concentrations of DTX induced radiosensitive G0/G1 and G2/M phase arrest, respectively, in ESCC cells.

Taxanes have demonstrated activity as a radiosensitizer in a number of preclinical and clinical studies by inhibiting the depolymerization of microtubules, and blocking the cell cycle in the most radiosensitive phase of the cell cycle (G2/M). In various tumor cells, the $\mathrm{G} 2 / \mathrm{M}$ phase is the most sensitive regarding radiation in comparison with normal cells because of deficient DNA repair during the G2-prophase period of the cell cycle $(37,38)$. Conversely, cells are known to be most radio-resistant in the late $\mathrm{S}$ phase. We found that a high concentration of DTX $(10 \mathrm{nM})$ induced the accumulation of cells in the G2/M phase and strongly enhanced the radiosensitivity of ESCC cells. Recently, taxanes have been reported to have a different mechanism of action depending on DTX dose intensity (34-36). It is well known that a high concentration of DTX $(100 \mathrm{nM})$ arrests cells in the G2/M phase. A low concentration of DTX can induce aberrant mitosis $(39,40)$. There has been limited evidence published concerning the effect of low concentrations of DTX concerning cell cycle arrest. The present study showed that a low concentration of DTX $(1 \mathrm{nM})$ induced the accumulation of ESCC cells in the sub-G0 and G0/G1 phases, indicating G0/G1 arrest. Morphologically, a low concentration of DTX induces multi-nucleation or unequal division. The cells are known to be most radioresistant in the $\mathrm{S}$ phase and most radiosensitive in the $\mathrm{G} 2 / \mathrm{M}$ phase. A low concentration of DTX may contribute to the enhancement of radiosensitivity in ESCC cells by means of cell cycle arrest in the radiosensitive G0/G1 phase and the induction of multinucleation or unequal division.

In the present study, although a low concentration of DTX induced very little apoptosis, irradiated cells after pretreatment with a low concentration of DTX exhibited a higher population of apoptotic cells relative to those irradiated without DTX pretreatment. In addition, after irradiation apoptotic cells are associated with an increased level of $\gamma \mathrm{H} 2 \mathrm{AX}$. When DNA DSBs are induced by radiation, the histone $\mathrm{H} 2 \mathrm{AX}$ is rapidly phosphorylated and forms $\gamma \mathrm{H} 2 \mathrm{AX}$ at the sites of the DSBs. Thus, $\gamma \mathrm{H} 2 \mathrm{AX}$ is considered as an indicator of DSBs. In the present study, we found that a low concentration of DTX, that did not cause a cytotoxic effect, could enhance radiosensitivity by enhancing radiation-induced DSBs and apoptosis.

Pradier et al (41) speculated that DTX seemed to be a better radiosensitizer for squamous cell carcinoma cells than PTX, because DTX enhances the radiosensitivity at lower concentrations than PTX. Cancer cells tested in vitro had $\mathrm{IC}_{50}$ values for DTX ranging from 5 to $50 \mathrm{nM}$ (42). However, the radiosensitizing activity of DTX in vitro was achieved even at subnanomolar concentrations. DTX concentrations as low as $0.07 \mathrm{nM}$ have been shown to potentiate the effects of irradiation in cell lines (41). Plasma levels of DTX reach their peak just after injection, and are metabolized relatively quickly. The pharmacokinetics and metabolism of DTX in vivo has been shown to have a three phase disposition profile with a terminal half-life of $12 \mathrm{~h}$ (43). DTX may be present for as long as 1 week, thus supporting the use of weekly DTX (44). From the elimination curve for patients receiving $20 \mathrm{mg} / \mathrm{m}^{2}$ of DTX, it can be speculated that the plasma concentration of DTX is maintained at a relatively high level $(>5 \mathrm{nM})$ for $\sim 48 \mathrm{~h}$ after administration, and at a relatively low level $(\sim 1 \mathrm{nM})$ after $48 \mathrm{~h}$ (44). It is speculated that DTX at a high plasma concentration has a cytotoxic effect and a strong radio-enhancing effect as a result of cell cycle arrest in the G2/M phase within $48 \mathrm{~h}$ after administration; however, thereafter the cytotoxic effect may disappear because of drug metabolization, maintaining its radio-enhancing activity as a result of cell cycle arrest in the G0/G1 phase. These results support the clinical use of weekly low dose DTX in combination with radiotherapy as reported in patients with oropharyngeal and hypopharyngeal carcinoma, non-small cell lung cancer and ESCC $(26,28,31)$.

Hennequin et al (16) reported that the radio-enhancing effect of taxoids varies from one cell line to another. DTX and PTX can reduce or enhance radiation cell killing, depending on the drug concentration. The full dosage of taxoids may provide suitable conditions for supra-additive interaction with radiation during concomitant exposure; conversely, induced radiation resistance by taxoids may occur in the low-drug dose range. An in vivo study indicated that the high level of radiation enhancement achieved by PTX occurs not at the time of the highest mitotic arrest but at 1 day after PTX treatment (45); this indicates that PTX potentiates tumor radio-responsiveness by mechanisms in addition to the blocking of the cell cycle in mitosis, by tumor reoxygenation of hypoxic tumor cells (46). In addition, wild-type p53 function is required to confer tumor cell sensitivity to DNA-damaging agents, such as ionizing radiation; the loss of p53 function in certain human tumor cells can lead to resistance to ionizing radiation (47). In the present study, we examined the radioenhancing effect of DTX in ESCC using the KES cell line that was newly established in our department, because KES cells are transplantable into the nude mouse. The p53 status in KES cells has not yet been investigated. To confirm the radiosensitizing effect of DTX according to its concentration in ESCC cells, further study to investigate its effects in other ESCC cell lines showing different p53 function in vitro is required. Furthermore, the radio-enhancing effect of DTX should be confirmed in vivo using a KES cell xenograft nude mouse model.

In conclusion, enhancement of the radiosensitivity of ESCC cells using DTX was demonstrated in vitro in the present study, even at a nanomolar concentration that did not induce cytotoxic effects. DTX has different radio-enhancing mechanisms that are concentration-dependent. Weekly administration of DTX might effectively enhance radiation cytotoxicity against ESCC. It will be necessary to elucidate the radio-enhancing mechanism of DTX in vivo. In addition, the benefit of weekly administration of low dose DTX in CRT regimens will need to be verified in the clinic. 


\section{References}

1. Castro C, Bosetti C, Malvezzi M, Bertuccio P, Levi F, Negri E, La Vecchia $\mathrm{C}$ and Lunet N: Patterns and trends in esophageal cancer mortality and incidence in Europe (1980-2011) and predictions to 2015. Ann Oncol 25: 283-290, 2014

2. Ohtsu A, Boku N, Muro K, Chin K, Muto M, Yoshida S, Satake M, Ishikura S, Ogino T, Miyata Y, et al: Definitive chemoradiotherapy for T4 and/or M1 lymph node squamous cell carcinoma of the esophagus. J Clin Oncol 17: 2915-2921, 1999.

3. Adelstein DJ, Li Y, Adams GL, Wagner H Jr, Kish JA, Ensley JF, Schuller DE and Forastiere AA: An intergroup phase III comparison of standard radiation therapy and two schedules of concurrent chemoradiotherapy in patients with unresectable squamous cell head and neck cancer. J Clin Oncol 21: 92-98, 2003.

4. Ishida K, Ando N, Yamamoto S, Ide H and Shinoda M: Phase II study of cisplatin and 5-fluorouracil with concurrent radiotherapy in advanced squamous cell carcinoma of the esophagus: A Japan Esophageal Oncology Group (JEOG)/Japan Clinical Oncology Group trial (JCOG9516). Jpn J Clin Oncol 34: 615-619, 2004

5. Herskovic A, Martz K, al-Sarraf M, Leichman L, Brindle J, Vaitkevicius V, Cooper J, Byhardt R, Davis L and Emami B: Combined chemotherapy and radiotherapy compared with radiotherapy alone in patients with cancer of the esophagus. N Engl J Med 326: 1593-1598, 1992.

6. Kaneko K, Ito H, Konishi K, Kurahashi T, Ito T, Katagiri A, Yamamoto T, Kitahara T, Mizutani Y, Ohtsu A, et al: Definitive chemoradiotherapy for patients with malignant stricture due to $\mathrm{T} 3$ or T4 squamous cell carcinoma of the oesophagus. Br J Cancer 88: 18-24, 2003

7. Choy H: Taxanes in combined modality therapy for solid tumors. Crit Rev Oncol Hematol 37: 237-247, 2001.

8. Ngeow J, Lim WT, Leong SS, Ang MK, Toh CK, Gao F, Chowbay B and Tan EH: Docetaxel is effective in heavily pretreated patients with disseminated nasopharyngeal carcinoma. Ann Oncol 22: 718-722, 2011.

9. Bang YJ, Kang WK, Kang YK, Kim HC, Jacques C, Zuber E, Daglish B, Boudraa Y, Kim WS, Heo DS, et al: Docetaxel 75 $\mathrm{mg} / \mathrm{m}(2)$ is active and well tolerated in patients with metastatic or recurrent gastric cancer: A phase II trial. Jpn J Clin Oncol 32: 248-254, 2002

10. Abbrederis K, Lorenzen S, von Weikersthal LF, VehlingKaiser U, Schuster T, Rothling N, Peschel C and Lordick F. Weekly docetaxel monotherapy for advanced gastric or esophagogastric junction cancer. Results of a phase II study in elderly patients or patients with impaired performance status. Crit Rev Oncol Hematol 66: 84-90, 2008.

11. Nuzzo F, Morabito A, Gravina A, Di Rella F, Landi G, Pacilio C, Labonia V, Rossi E, De Maio E, Piccirillo MC, et al: Effects on quality of life of weekly docetaxel-based chemotherapy in patients with locally advanced or metastatic breast cancer: Results of a single-centre randomized phase 3 trial. BMC Cancer 11: 75, 2011.

12. Gravis G, Bladou F, Salem N, Macquart-Moulin G, Serment G, Camerlo J, Genre D, Bardou VJ, Maraninchi D and Viens P Weekly administration of docetaxel for symptomatic metastatic hormone-refractory prostate carcinoma. Cancer 98: 1627-1634, 2003

13. Perng RP, Shih JF, Chen YM, Chou KC, Lee YC and Tsai CM: A phase II study of single-agent docetaxel chemotherapy for non-small cell lung cancer. Jpn J Clin Oncol 30: 429-434, 2000.

14. Kawada K, Kitagawa K, Kamei S, Inada M, Mitsuma A, Sawaki M, Kikumori T, Fujimoto Y, Arima H, Imai T, et al: The feasibility study of docetaxel in patients with anaplastic thyroid cancer. Jpn J Clin Oncol 40: 596-599, 2010.

15. Muro K, Hamaguchi T, Ohtsu A, Boku N, Chin K, Hyodo I, Fujita H, Takiyama W and Ohtsu T: A phase II study of singleagent docetaxel in patients with metastatic esophageal cancer. Ann Oncol 15: 955-959, 2004.

16. Hennequin $\mathrm{C}$, Giocanti $\mathrm{N}$ and Favaudon V: Interaction of ionizing radiation with paclitaxel (Taxol) and docetaxel (Taxotere) in HeLa and SQ20B cells. Cancer Res 56: 1842-1850, 1996.

17. Balcer-Kubiczek EK, Attarpour M, Wang JZ and Regine WF: The effect of docetaxel (taxotere) on human gastric cancer cells exhibiting low-dose radiation hypersensitivity. Clin Med Oncol 2: 301-311, 2008
18. Mason KA, Hunter NR, Milas M, Abbruzzese JL and Milas L: Docetaxel enhances tumor radioresponse in vivo. Clin Cancer Res 3: 2431-2438, 1997.

19. Yoshida T, Tokashiki R, Itoh H, Nakamura K, Hiramatsu $H$, Tsukahara K, Shimizu S, Takada D, Okamoto I, Abe K, et al: A phase I-II study of bi-weekly docetaxel combined with radiation therapy for patients with cancer of the larynx/hypopharynx. Jpn J Clin Oncol 37: 641-646, 2007.

20. Li YQ, Shi AH, Li FH, Yu R and Zhu GY: Phase I study to determine MTD of docetaxel and cisplatin with concurren radiation therapy for Stage III non-small cell lung cancer. Chin J Cancer Res 23: 129-133, 2011.

21. Kiura K, Ueoka H, Segawa Y, Tabata M, Kamei H, Takigawa N, Hiraki S, Watanabe Y, Bessho A, Eguchi K, et al; Okayama Lung Cancer Study Group: Phase I/II study of docetaxel and cisplatin with concurrent thoracic radiation therapy for locally advanced non-small-cell lung cancer. Br J Cancer 89: 795-802, 2003.

22. Tishler RB, Norris CM Jr, Colevas AD, Lamb CC, Karp D, Busse PM, Nixon A, Frankenthaler R, Lake-Willcutt B, Costello R, et al: A Phase I/II trial of concurrent docetaxel and radiation after induction chemotherapy in patients with poor prognosis squamous cell carcinoma of the head and neck. Cancer 95: 1472-1481, 2002

23. Fujii M, Tsukuda M, Satake B, Kubota A, Kida A, Kohno N, Okami K and Inuyama Y; Japan Cooperative Head and Neck Oncology Group (JCHNOG): Phase I/II trial of weekly docetaxel and concomitant radiotherapy for squamous cell carcinoma of the head and neck. Int J Clin Oncol 9: 107-112, 2004.

24. Tishler RB, Posner MR, Norris CM Jr, Mahadevan A, Sullivan C, Goguen L, Wirth LJ, Costello R, Case M, Stowell S, et al: Concurrent weekly docetaxel and concomitant boost radiation therapy in the treatment of locally advanced squamous cell cancer of the head and neck. Int J Radiat Oncol Biol Phys 65: 1036-1044, 2006.

25. Clark JI, Eisner RM, Hofmeister C, Norton J, Thomas S, Choudhury A, Petruzzelli G, Lathers D, Young MR, Lau A, et al: Phase I adjuvant radiation with docetaxel in high-risk head and neck cancer. Am J Clin Oncol 32: 396-400, 2009.

26. Fukada J, Shigematsu N, Takeda A, Ohashi T, Tomita T, Shiotani A, Kunieda E, Kawaguchi O, Fujii M and Kubo A: Weekly low-dose docetaxel-based chemoradiotherapy for locally advanced oropharyngeal or hypopharyngeal carcinoma: A retrospective, single-institution study. Int J Radiat Oncol Biol Phys 76: 417-424, 2010.

27. Onishi H, Kuriyama K, Yamaguchi M, Komiyama T, Tanaka S, Araki T, Nishikawa K and Ishihara H: Concurrent two-dimensional radiotherapy and weekly docetaxel in the treatment of stage III non-small cell lung cancer: A good local response but no good survival due to radiation pneumonitis. Lung Cancer 40: 79-84, 2003.

28. Brunsvig PF, Hatlevoll R, Berg R, Lauvvang G, Owre K, Wang M and Aamdal S: Weekly docetaxel with concurrent radiotherapy in locally advanced non-small cell lung cancer: A phase I/II study with 5 years' follow-up. Lung Cancer 50: 97-105, 2005.

29. Kunos CA, Sill MW, Buekers TE, Walker JL, Schilder JM, Yamada SD, Waggoner SE, Mohiuddin M and Fracasso PM: Low-dose abdominal radiation as a docetaxel chemosensitizer for recurrent epithelial ovarian cancer: A phase I study of the Gynecologic Oncology Group. Gynecol Oncol 120: 224-228, 2011.

30. Font A, Arellano A, Fernández-Llamazares J, Casas D, Boix J, Cardenal J, Margelí M, Manzano JL, Abad A and Rosell R: Weekly docetaxel with concomitant radiotherapy in patients with inoperable oesophageal cancer. Clin Transl Oncol 9: 177-182, 2007.

31. Makino I, Okamoto K, Kinoshita J, Hayashi H, Nakamura K, Oyama K, Nakagawara H, Fujita H, Tajima H, Takamura H, et al: A pilot study of chemoradiotherapy with weekly docetaxel for thoracic esophageal carcinoma with T4 and/or M1 lymph node metastasis. World J Oncol 2: 252-258, 2011.

32. Kushida T, Nohara S, Yoshino K, Fujiwara D, Ouchi K, Amano T, Isayama F, Tomita N, Iwanuma Y, Sasai K, et al: Utility of weekly docetaxel combined with preoperative radiotherapy for locally advanced esophageal cancer from pathological analysis. Dis Esophagus 27: 368-373, 2014.

33. Moos PJ and Fitzpatrick FA: Taxanes propagate apoptosis via two cell populations with distinctive cytological and molecular traits. Cell Growth Differ 9: 687-697, 1998.

34. Torres K and Horwitz SB: Mechanisms of Taxol-induced cell death are concentration dependent. Cancer Res 58: 3620-3626, 1998. 
35. Hernández-Vargas H, Palacios J and Moreno-Bueno G: Telling cells how to die: Docetaxel therapy in cancer cell lines. Cell Cycle 6: 780-783, 2007.

36. Zhang D, Yang R, Wang S and Dong Z: Paclitaxel: New uses for an old drug. Drug Des Devel Ther 8: 279-284, 2014.

37. Chaffey JT and Hellman S: Differing responses to radiation of murine bone marrow stem cells in relation to the cell cycle. Cancer Res 31: 1613-1615, 1971.

38. Parshad R, Gantt R, Sanford KK and Jones GM: Chromosomal radiosensitivity of human tumor cells during the $\mathrm{G} 2$ cell cycle period. Cancer Res 44: 5577-5582, 1984.

39. Paoletti A, Giocanti N, Favaudon V and Bornens M: Pulse treatment of interphasic HeLa cells with nanomolar doses of docetaxel affects centrosome organization and leads to catastrophic exit of mitosis. J Cell Sci 110: 2403-2415, 1997.

40. Morse DL, Gray H, Payne CM and Gillies RJ: Docetaxel induces cell death through mitotic catastrophe in human breast cancer cells. Mol Cancer Ther 4: 1495-1504, 2005.

41. Pradier O, Rave-Fränk M, Lehmann J, Lücke E, Boghun O, Hess CF and Schmidberger H: Effects of docetaxel in combination with radiation on human head and neck cancer cells (ZMK-1) and cervical squamous cell carcinoma cells (CaSki). Int J Cancer 91: 840-845, 2001
42. Clarke SJ and Rivory LP: Clinical pharmacokinetics of docetaxel. Clin Pharmacokinet 36: 99-114, 1999.

43. Bruno R and Sanderink GJ: Pharmacokinetics and metabolism of Taxotere (docetaxel). Cancer Surv 17: 305-313, 1993.

44. Brunsvig PF, Andersen A, Aamdal S, Kristensen V and Olsen H: Pharmacokinetic analysis of two different docetaxel dose levels in patients with non-small cell lung cancer treated with docetaxel as monotherapy or with concurrent radiotherapy. BMC Cancer 7: 197, 2007.

45. Milas L, Hunter NR, Mason KA, Kurdoglu B and Peters LJ: Enhancement of tumor radioresponse of a murine mammary carcinoma by paclitaxel. Cancer Res 54: 3506-3510, 1994.

46. Milas L, Hunter NR, Mason KA, Milross CG, Saito Y and Peters LJ: Role of reoxygenation in induction of enhancement of tumor radioresponse by paclitaxel. Cancer Res 55: 3564-3568, 1995.

47. McIlwrath AJ, Vasey PA, Ross GM and Brown R: Cell cycle arrests and radiosensitivity of human tumor cell lines: Dependence on wild-type p53 for radiosensitivity. Cancer Res 54: 3718-3722, 1994 